\title{
ECTOHYDRICITY OF LICHENS AND ROLE OF CORTEX LAYER IN ACCUMULATION OF HEAVY METALS
}

\author{
EKTOHYDRYCZNOŚĆ POROSTÓW I ROLA WARSTWY KOROWEJ \\ W AKUMULACJI METALI CIĘŻKICH
}

\begin{abstract}
Heavy metal and dust pollution absorption through lichen thallus occurs on the surface, that is by means of ectohydric sorption . Protective mechanisms, among which there is heterometric (layered) structure of lichens, play a significant role in limiting this process. The aim of this research was to determine the way the pollution penetrates inside lichen thallus and to determine the role of dermal layer in stopping heavy metals on the thallus surface . Lichen thalli exposed to transport pollution near Krakow-Katowice motorway for half a year were analyzed. With the use of Electron Scanning Microscope Quanta 250 and microanalyser EDEX accumulation of pollutions depositing on the outer lichen surface, on the surface of algal cells, in subcortex layer, on the fungal hyphae surface and intercellular spaces of crack bottom of pseudocyphella were determined. The results of the analysis show an important role of pseudocyphella in the process of pollution penetration inside lichen thallus and protective effectiveness of the upper cortex whose tight structure and thickness of chitinous cell walls of mycelium, relatively thicker in comparison to parenchyma layer, influence its dermal properties. Heavy metal accumulation $(\mathrm{Al}, \mathrm{Fe}, \mathrm{Cu})$ on the thallus surface, on algal cell surface, on the fungal hyphae surface and deep layers of pseudocyphella cracks is presented by the order: crack $>$ alga $>$ fungi $>$ subcortex layer $>$ thallus surface.
\end{abstract}

Keywords: lichen thallus, protective mechanisms, dermal layer, pseudocyphella, heavy metals pollution

\section{Introduction}

The bioindicative research goes back to times of Linnaeus. His famous plant sundial gave rise to the possibility of using the organism's response to changing habitat conditions. At the turn of the eighteenth and nineteenth centuries W. Nylander [1] independently conducted research on lichens and mosses sensitivity to air pollution. These were the beginnings of bioindicative research that since the eighteenth century, with varying intensity, are introduced into science. In Poland, a pioneer in research on the lichens was Rev. J.K. Kluk (1739-1796). He listed in the plant dictionary 40 species of lichens, describing their habitat, and their practical use.

Bioindication method allows the assessment of the impact of environmental factors on biomarkers organisms. It is based on the analysis of their diversity and abundance,

\footnotetext{
${ }^{1}$ Department of Environment Protection and Modelling, The Jan Kochanowski University, ul. Świętokrzyska 15, 25-406 Kielce, Poland, phone +48 4134964 34, fax +48 4134964 18, email: malgorzata.jozwiak@vp.pl
} 
anatomical and morphological, physiological changes, as well as the study of the chemical composition of elements accumulated in the cells and tissues of biomarkers. For the evaluation of changes in biotope is used lichenoindication scale, which was proposed by Hawksworth and Rose [2]. It allows, on the basis of lichenobiota's species list, assess the level of air pollution in the study area. In Poland, this method was used by: Zurzycki [3], Wilkon-Michalska et al [4], Cieslinski [5], Kiszka [6], Faltynowicz et al [7], Kiszka [8], Kiszka and Koscielniak [9], Matwiejuk [10]. Kiszka [11] modified the 10-point scale of Hawksworth and Rose offering 7-point scale, which is used to assess the pollution of Krakow Voivodeship and the city of Przemysl. Chemical-analytical methods involving the study of the chemical composition of elements accumulated in thallus have been used by many authors. The results clearly show the validity of use of lichens for accumulation of contaminants present in the air.

Such studies were conducted by Bylinska, Seaward and Kwapulinski [12] and related to the accumulation of heavy metals and radionuclides in lichens growing in the south-western part of the Poland. Kiszka and Grodzinska [13] using lichens, evaluated the degree of contamination of the Niepolomice Forest's area. Miszalski [14] research into the sensitivity of lichens to sulphur dioxide, and Marska [15] conducted research on the impact of industrial emissions on lichens exhibited around the chemical plant "Police". Research on comparison metals concentration $\mathrm{Cr}, \mathrm{Cu}, \mathrm{Fe}, \mathrm{Ni}, \mathrm{Pb}$ and $\mathrm{Zn}$ in lichens Hypogymnia physodes exposed in Bialystok and in the Knyszynski Forest was carried out in 2001. Chibowski and Reszka [16] studied the concentration of heavy metals and radionuclides in lichens exposed in the area of Lublin. In the vicinity of Krakow was analyzed the distribution of elements in the structure of Hypogymnia physodes lichen exposed in the woods [17]. Migaszewski [18, 19] used Hypogymnia physodes to designate contaminated areas Swietokrzyskie Mountains and Wigry National Park. Since 2004 monitoring of heavy metals air pollution and PAHs in urban run by M.A. Jozwiak, M. Jozwiak [20, 21] is going on. It is using in the active methods of monitoring involving the transplantation of lichen methods. Extensive biomonitoring research using lichen was conducted in Bory Strobawskie by Klos et al [22].

Use of lichen as bio-accumulators has also numerous examples in the world researches. In Portugal, in the early 90s was introduced environment pollution assessment program based on analysis of trace element concentrations in lichens. Particular emphasis was placed on monitoring the coast of the Atlantic Ocean [23, 24] with respect to the industrial area at the mouth of the River Sado [25]. Usefulness of lichens to assess environmental pollution was used many times in Israel. In research were used Caloplaca aurantia and Ramalina duriaei. Area of Tel Aviv [26], environs of industrial city Ashod [27] environs of fossil-fuel power stations [28] and low polluted agricultural areas [27]. In Italy, one of the examples of the use of lichens to assess environmental pollution was research in the area around the volcano Etna in Sicily and on the volcanic island of Vulcano (Tuscany, Italy). The aim of the studies was to analyze the trace elements accumulated in lichens, including Parmelia conspersa and Xanthoria calcicola. The results were interpreted with use of enrichment factors $E F$. As the reference element were adopted scandium [29] and aluminum [30]. The correlation between the concentration of elements in volcanic dust and gases and their concentrations in lichens was demonstrated. The areas around the geothermal springs, near Larderello, Bagnore and Piancastagniano [31] and the area around the mine of mercury ores were also examined [33]. 
In Tuscany has been searching for correlation between the content of heavy metals: Al, $\mathrm{Cu}, \mathrm{Fe}, \mathrm{Hg}, \mathrm{Mn}$, Mo and $\mathrm{Zn}$ in lichens P.c.a., bark and leaves of oak [33]. In the province of Livorno was monitored area of $1437 \mathrm{~km}^{2}$. Concentrations of metals in lichens Xanthoria parietina were examined. In areas where has been assigned a value of $I A P<10$, high concentrations of $\mathrm{Hg}, \mathrm{Cd}$ and $\mathrm{Pb}$ was stated [34]. Similar studies were carried out in Buenos Aires (Argentina), using naturally occurring lichens Parmotrema reticulatum and transplanted lichens Usnea sulicata. Appointed enrichment factor EF to Sc showed a significant heavy metal pollution, including $\mathrm{Sb}, \mathrm{Zn}, \mathrm{Br}$ [35]. Another example of use of lichenoindication methods in assessment of the environment in Argentina is research conducted in the province of Cordoba [36] and in the city of Bariloche [37]. The analysis of elements focused in lichens Xanthoria parietina, growing in the vicinity of Izmir (Turkey), showed an increased concentration of $\mathrm{Mn}, \mathrm{Fe}, \mathrm{Cr}$ and $\mathrm{Sb}$ near the steelworks. In the lichens were recorded also increased concentrations of arsenic, which is released into the atmosphere during combustion of coal [38]. Moreover the linear dependencies in the concentration of mercury, copper, nickel and lead in the studied two species of lichens Xanthoria parietina and Parmelia tiliacea were appointed [39]. A greater concentration of metals in lichens Parmelia tiliacea was also stated. In 1992, in Slovenia from 86 sites Hypogymnia physodes lichen samples were collected. It was analyzed the IAP index value and the contents of trace elements. An area with the largest concentration of impurities was marked out [40]. Also detailed research around the mines and processing of natural gas [41] and around the coal power stations was carried out [42].

Often the test area, pointing to the global anthropogenic pollution level is the Arctic and Antarctica, where the emissions associated with the development of civilization can be assumed to be equal to zero. Heavy metals were studied for example in Alaska [43], Greenland [44], Shetland [45], on Spitsbergen [46] and in the areas of the H. Arctowski Polish Antarctic Station [47]. One of examples is the study of heavy metal concentrations in lichens Usnea antarctica and Usnea aurantiaco-atra collected in 1995-1996 in the area of the Polish and Brazilian Arctic station in Admiralty Bay [48]. It was found out that the variable distribution of concentrations of $\mathrm{Mn}, \mathrm{Pb}$ and $\mathrm{Zn}$ in lichens collected and transplanted in the study area due to different climatic conditions and was depending on the direction of winds. The authors also paid attention to the increasing level of anthropogenic pollution in the Antarctic regions.

In most cases, lichens were used only as biological contaminants absorbents, especially of heavy metals. Little attention has been paid to the mechanisms and roads of contamination penetration or morphological changes that occur under anthropogenic stress which consequently lead to the loss of lichen biota in excessively polluted areas.

Bioindication of lichens is a result of their morphological and anatomical features and metabolic reactions sensitivity to stress-making factors. Observed in thalluses metabolic disorders occurring at the cellular level and are both in the mykobiont and fotobiont cells. Therefore dualistic nature of lichens gives this ecological group a number of specific features.

Organism commonly used for the analysis of air pollution is the epiphyte of tree trunks, windhover H.ph. Using this lichen species for bioindicative tests results from the bioindicative features [20, 49-52]. It is a typical epiphyte lichen, with a wide geographical spread. Due to the lack of association between physiological processes and the seasons, research lichen trials sampling can be carried out in accordance with the methodological 
assumptions, in any specified period of time. The availability of the thalluses is unlimited, their transportation, segregation, storage and cataloging is easy due to the leaf-structure of the lichen. Hypogymnia physodes accumulate contaminants as a result of direct contact with the surface of the lichen. The ingress of contaminants is carried out along with the processes of absorption of moisture in the ambient air, the process occurs intensive due to the dorsoventral, widely flattened thallus structure [53]. Thallus H.ph. is heteromeric and consists of well-separated layers: mushroom in form of bark, algae, flesch - loosened mycelium and the lower cortex, forming rhizoid (Fig. 1).

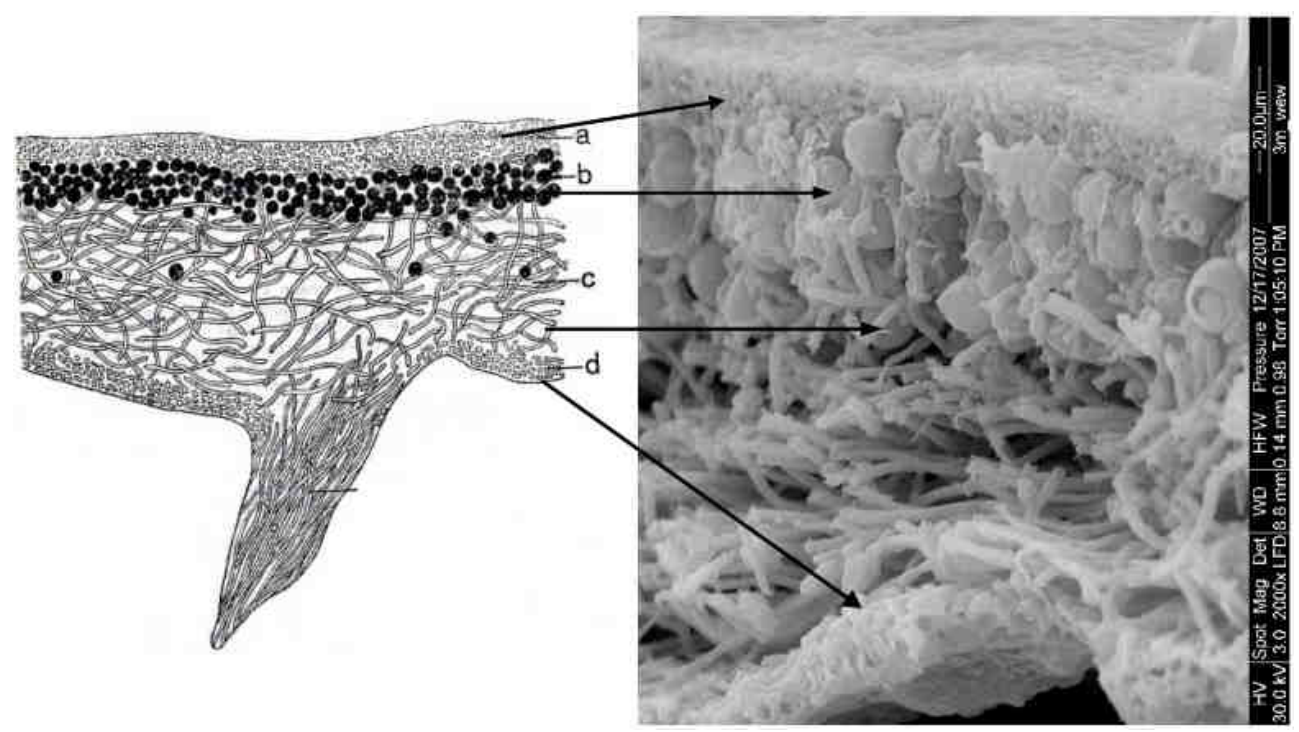

Explanations: a - apper cortex, b - algal layer, c - medulla, $\mathrm{d}$ - lower cortex

Fig. 1. Corss-section of a lichen thallus heteromeric
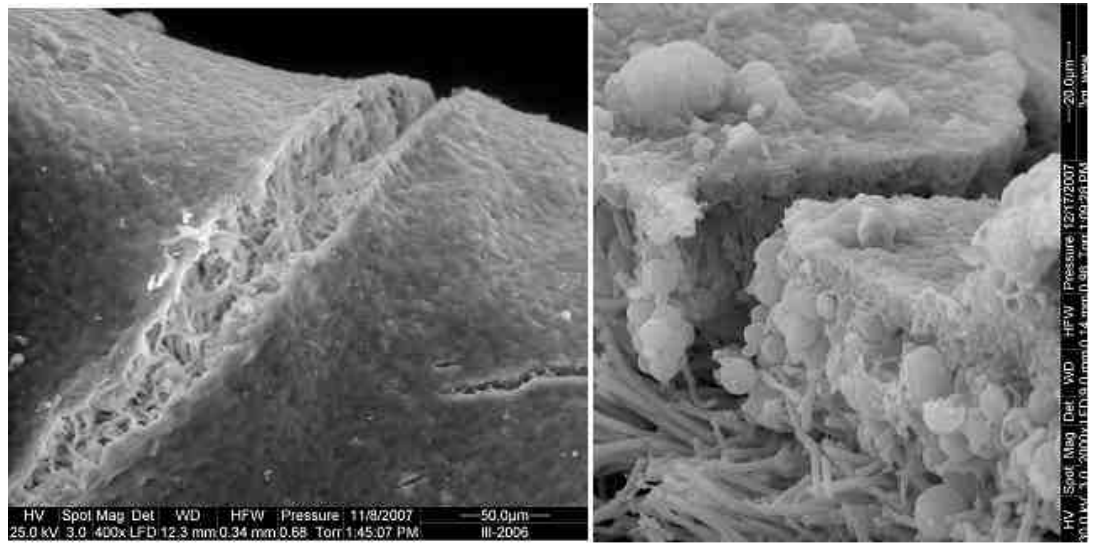

Photo 1. Slot unveiling of cells under upper cortex Hypogymnia physodes (L.) Nyl. thalli (photo M.A. Jozwiak) 
The characteristic features of frond lichens is to produce bodies to facilitate gas exchange. They are called pseudocyphellum or respiratory slots, and are described as a crack or a loosening of the bark layer. They occur on the surface of the thallus and connect with each other with nets revealing sub-bark layer (Fig. 1). They are also the places of penetration of impurities.

Contact of thallus with toxin does not lead to its immediate death, but causes the accumulation of pollutants in the body. This mechanism is possible due to transport of water, and with it pollutants such as heavy metals and polycyclic aromatic hydrocarbons (PAHs), dioxins, dust particles [54, 55]. Biosorption, or passive interaction with metals, when the positive metal ions are bound by the functional groups of the cell walls of fungus and algae cells and bio-accumulation resulting from the transport into the cells through the cell membrane into the cytoplasm is possible due to anatomical specificity of algae-fungal thallus structure [56, 57].

Cell walls of mycelial cells in the transmission electron microscope image show multiple layers of chitin that surrounds them. (Photo 2). It forms a thick layer, and has the protection properties and characteristics substantially better than cellulose cell walls of algae (Photo 3), as shown by numerous physico-chemical studies. This may suggest the presence of characteristic to lichen "dermal layer"

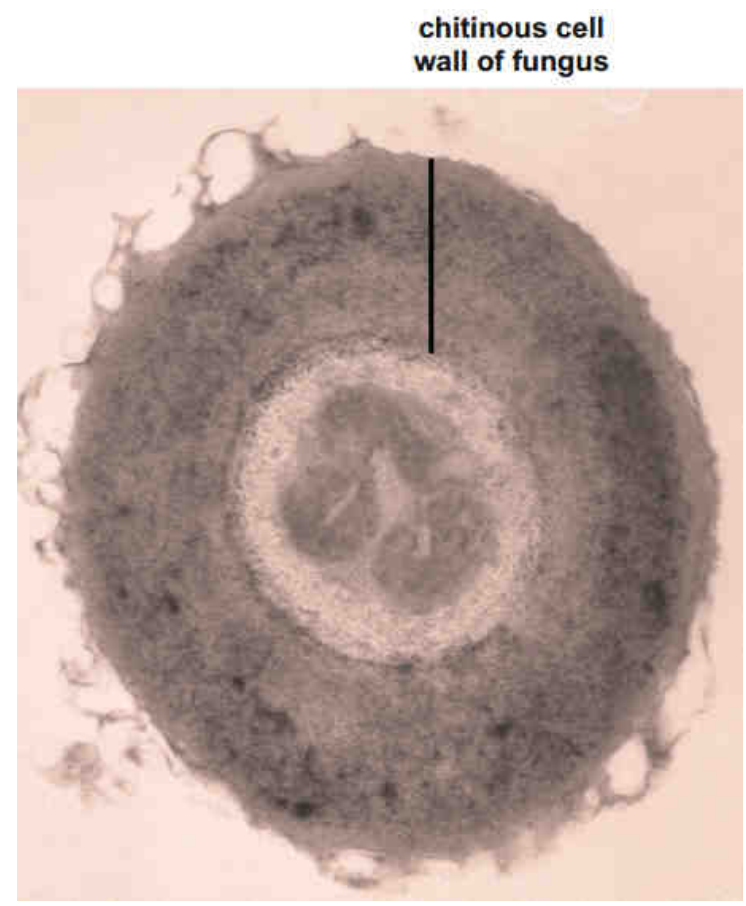

Photo 2. Chitinous cell wall of fungus with Hypogymnia physodes thalli (photo M.A. Jozwiak)

Ascomycetes mycelium cell wall is composed of a polysaccharide of $\mathrm{N}$-acetyl-D-glucosamine, chitin $\left(\mathrm{C}_{8} \mathrm{H}_{13} \mathrm{O}_{5} \mathrm{~N}\right) \mathrm{n}$, and chitosan, organic substance, 
polysaccharide, which is a derivative of chitin, which is formed by chemical deacetylation of chitin.

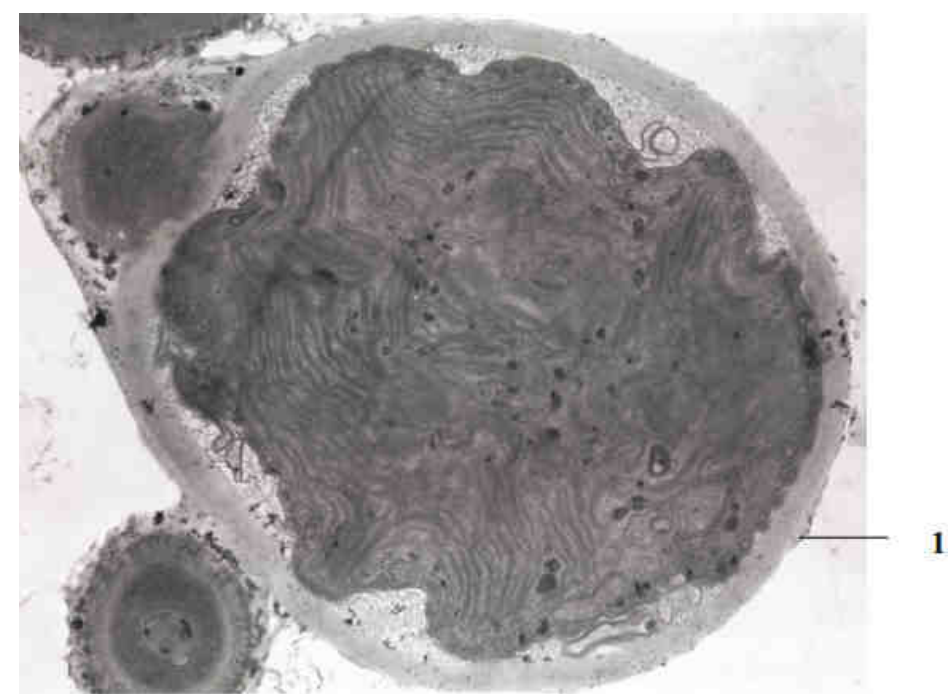

Photo 3. Cellulose cell wall of algae Trebouxia sp. with Hypogymnia physodes thallus (photo M.A. Jozwiak); 1 - cellulose cell wall of algae

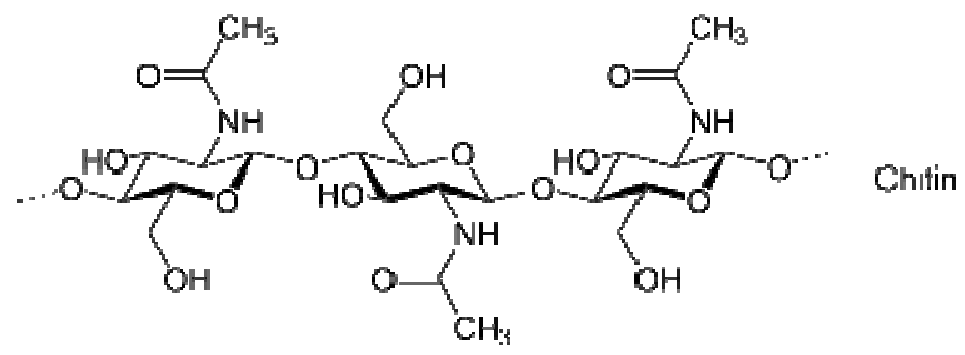

Chitin-Deacetylase

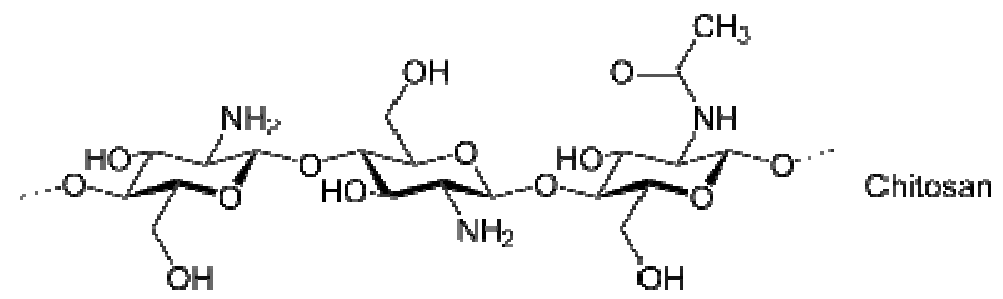

Fig. 2. Formation of chitosan by partial deacetylation of chitin [58] 
Chitin instead of glucosidic units have acetylglucosamine units forming polymer chains. The exchange of oxygen atoms for nitrogen atoms in chitin in relation to cellulose results in the occurrence of strong hydrogen bonds, which increases the mechanical strength of the chitin [58]. It also has a high value of secondary swelling indicator, high bioadhesivity and hygroscopic and imbibitic properties.

Chitosan is the product of deacetylation of chitin. Both of these materials are linear polymers. The special properties of chitosan due to its ability to installation in its structure of toxic heavy metals, therefore it has chelating properties [59]. Creation of chelate complexes on the surface of lichen thalluses causes action of chemical protective mechanisms operating at the crossroads - the polluted air and the surface of the thallus (Photo 4). Microcrystalline chitosan is present in the walls of the mycelium shreds, due to the ability to form polymeric membranes directly from the slurry, high adhesiveness, antimicrobial properties, and high sorption capacity plays an important role in thalluses protection against atmospheric pollution.

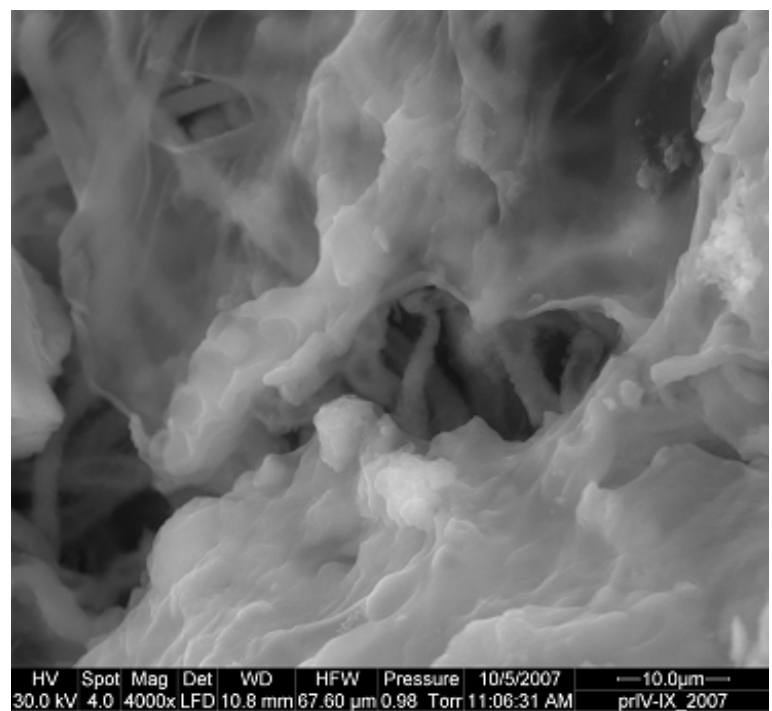

Photo 4. Creation of chelate complexes on the surface of lichen thallus Hypogymnia physodes (photo M.A. Jozwiak)

The aim of the research was to identify the absorption routes and areas of depositing selected heavy metals in lichen thalli, transplanted in linear emission zones exposed to transit contaminants, as well as to examine the protective function of thallus upper cortex viewed as a dermal layer for retention of heavy metals on thallus surface.

\section{Methods and materials}

Fieldwork and laboratory research methods were used in the study. The transplants were placed 1.5-2.0 $\mathrm{m}$ high ASL alongside the Cracow-Katowice motorway. The exposure lasted 6 months. Lichen thallus hyphae were used which demonstrated colour changes, as verified by Nikon SMZ 1500 stereoscopic microscope and thallus control samples (without 
colour changes). Observation of thallus's inside and surface were made by FEI QUANTA 250 electron microscope. EDS type microanalyzer was used for analysis too, which made it possible to carry out random and area chemical analyses of Hypogymnia physodes thallus surface, fleshy layer, mycobiont's and photobiont's cell wall surfaces. EDS microanalizer makes it possible to conduct qualitative and quantitative analyses of elemental breakdown by scanning random spots (random method), along a line or an area (mapping). For the microscopic observation, the sample was sputtered with gold by IEE-4C Vacuum Evaporator. Qualitative analysis consists in identification of particular elements in $\mathrm{X}$-radiation spectrum.

\section{Results}

Through analysis of Hypogymnia physodes thallus samples exposed alongside the Cracow-Katowice motorway, significant colour changes visible in the stereoscopic microscope image were found - mostly in form of bronzing and necrotic blackening (Photos 5 and 6).

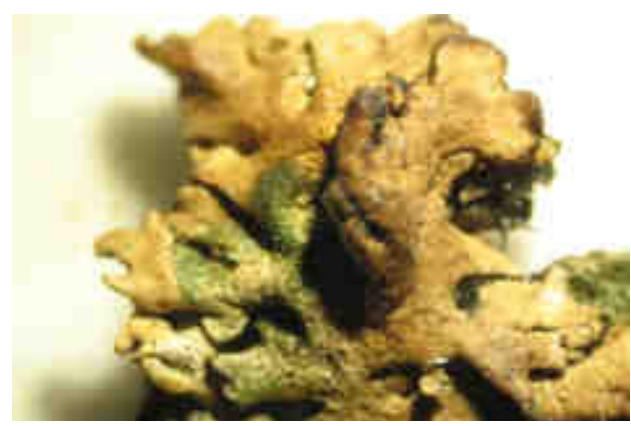

Photo 5. Browning of the surface of transplanted thallus Hypogymnia physodes (L.) Nyl. The image from stereoscopic microscope (photo M.A. Jozwiak)

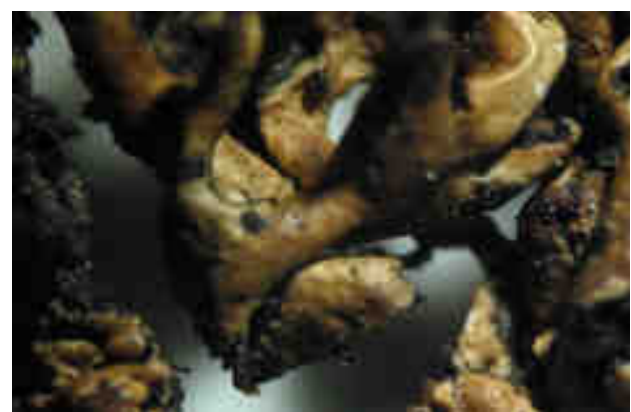

Photo 6. Necrotic blackness of the surface of transplanted thallus Hypogymnia physodes (L.) Nyl. (photo M.A. Jozwiak)

Research conducted in the areas of these changes by means of EDAX microanalyzer showed heavy metals adsorbed on the thalli's surfaces (Fig. 3, Photo 7), in sub-cortex layer (Fig. 4, Photo 8), algal cells' surface (Fig. 5), fungal hyphae surface (Fig. 6, Photo 9) 
located in fleshy layer (Fig. 7, Photo 10) as well as gaseous exchange pores. Diversified accumulation in each of the thallus areas is presented in Table 1.

Table 1

Accumulation of heavy metals in different areas of the thallus Hypogymnia physodes (L.) Nyl.

\begin{tabular}{|c|c|c|c|}
\hline \multirow{3}{*}{ Site analysis } & \multicolumn{3}{|c|}{ Heavy metals } \\
\hline & Al & Fe & $\mathbf{C u}$ \\
\hline & \multicolumn{3}{|c|}{ [wt.\%] } \\
\hline \multicolumn{4}{|c|}{ Sample befoure exposure } \\
\hline Thallus surface - upper cortex & 0.12 & 0.07 & 0.08 \\
\hline Subcortex layer & 0.11 & 0.07 & 0.04 \\
\hline Fungal hyphae surface of parenchyma layer & 0.23 & 0,12 & 0.16 \\
\hline Algal cells surface of parenchyma layer & 0.24 & 0.11 & 0.17 \\
\hline Intercellural spaces of pseudocyphella cracks & 0.27 & 0.34 & 0.21 \\
\hline \multicolumn{4}{|c|}{ Sample after exposure } \\
\hline \multirow{4}{*}{ Thallus surface - upper cortex } & 0.97 & 0.9 & 0.2 \\
\hline & 2.12 & 1.05 & 0.11 \\
\hline & 1.28 & 0.06 & 0.91 \\
\hline & 0.23 & 0.00 & 0.15 \\
\hline \multirow{4}{*}{ Subcortex layer } & 0.23 & 0.00 & 0.25 \\
\hline & 0.19 & 0.00 & 0.23 \\
\hline & 0.09 & 0.06 & 0.12 \\
\hline & 0.09 & 0.04 & 0.11 \\
\hline \multirow{4}{*}{ Fungal hyphae surface of parenchyma layer } & 3.27 & 5.89 & 3.74 \\
\hline & 0.72 & 1.75 & 1.14 \\
\hline & 1.14 & 1.92 & 1.11 \\
\hline & 4.09 & 3.98 & 2.93 \\
\hline \multirow{4}{*}{ Algal cells surface of parenchyma layer } & 5.77 & 0.13 & 0.38 \\
\hline & 7.33 & 10.41 & 4.17 \\
\hline & 1.44 & 2.6 & 1.16 \\
\hline & 2.27 & 0.93 & 1.66 \\
\hline \multirow{4}{*}{ Intercellural spaces of pseudocyphella cracks } & 8.97 & 5.93 & 3.56 \\
\hline & 1.99 & 1.72 & 1.05 \\
\hline & 2.23 & 2.12 & 2.17 \\
\hline & 3.96 & 1.12 & 0.76 \\
\hline
\end{tabular}

Analysis of the result allows to make an assertion that the highest accumulation occurred for aluminium (average $4.28 \mathrm{wt} . \%$ ) in intercell respiratory gaps and respectively on gonidial cells' surface (average $4.20 \mathrm{wt} . \%$ ) and on the surface of subcortex layer mycelium hyphae (average.2.30 wt.\%). The amount of aluminium adsorbed on the thallus surface and in subcortex layer placed directly under upper cortex layer (average $1.15 \mathrm{wt} . \%$ surface, average $0,15 \mathrm{wt} . \%$ - subcortex layer) points to its protective role in relation to Al. An increase in value of this metal accumulation in the vicinity of thallus cracks (pseudcyphella) was observed. This happens as it is convenient for contaminants to be deposited in the cracks, in thallus roughness on the surface of the exposed mycelium and algal cells as well as intercell gaps.

Analysis of $\mathrm{Fe}$ accumulation areas in thalli points to adsorption on algal cells' surfaces (average $3.58 \mathrm{wt} . \%$ ) and respectively on the surface of mycelium cells (average $3.385 \mathrm{wt} . \%$ ) and in respiratory pores (average $2.72 \mathrm{wt} \%$ ). Amount of iron adsorbed on the thallus surface and in subcortex layer (average $0.5 \mathrm{wt} . \%$ on surface; average $0.02 \mathrm{wt} \%$ subcortex 
layer) corroborates protective properties of thallus surface layer which were found in relation to aluminium.

$\mathrm{Cu}$ accumulation was found first and foremost in the fleshy layer on the surface of mycelium hyphae (average 2.23 wt.\%) and in intercell gaps of pseudocyphella cracks (average 1.89 wt.\%). Small amounts were found also in the thallus surface in upper cortex (average $0.343 \mathrm{wt} . \%$ ) and in subcortex layer (average $0.178 \mathrm{wt} . \%$ ).

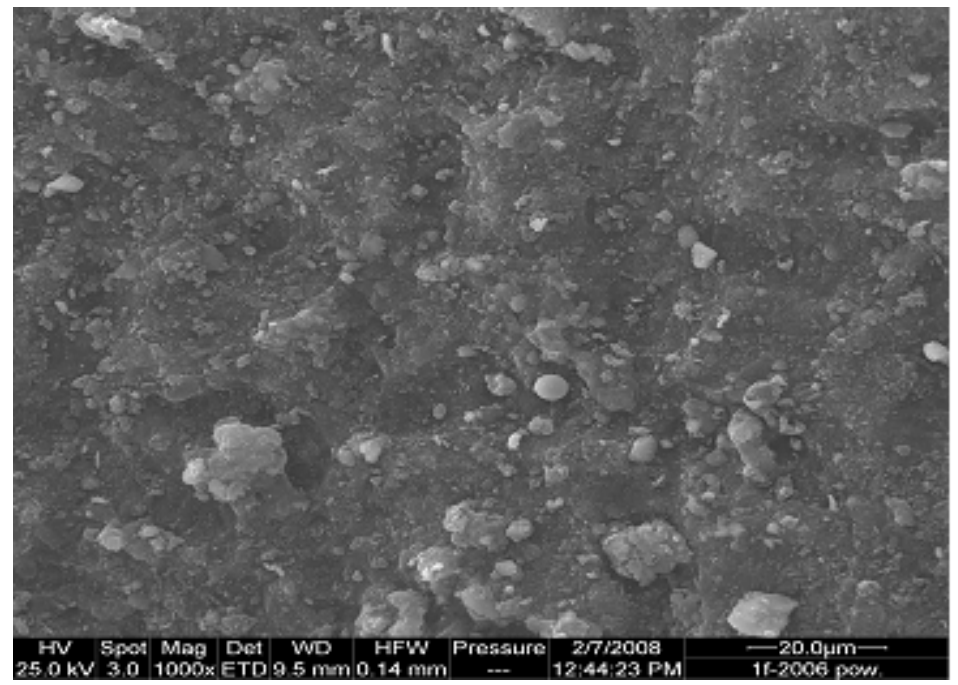

Photo 7. Surface of Hypogymnia physodes (L.) Nyl. thallus. Image form electron microscope (photo M.A. Jozwiak); resolution 1000x

CiArchivelUSERIKLIENTRpborecianalizßlf-2006 pow.spc

Label A: 1f-2006pow

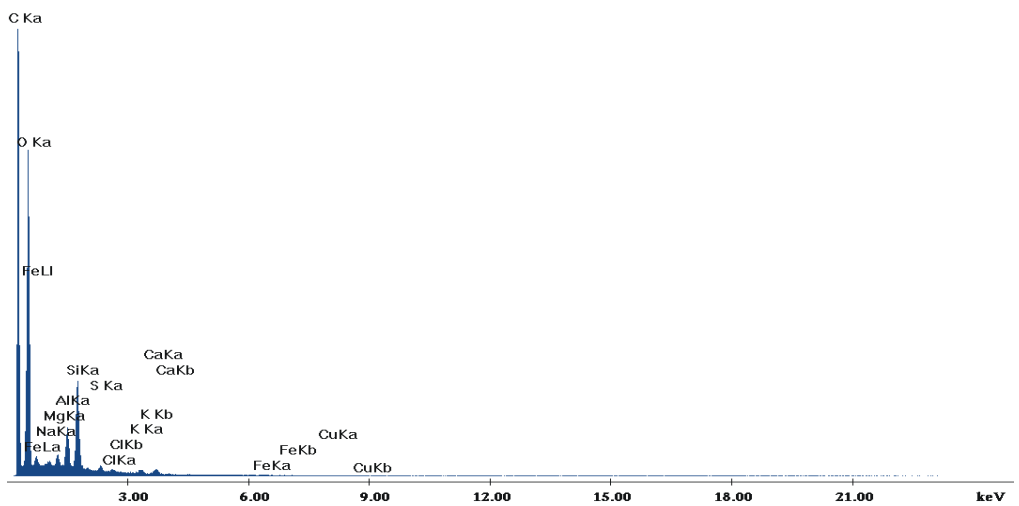

Fig. 3. Chemical analyses EDS of thallus surface of Hypogymnia physodes (L.) Nyl. 


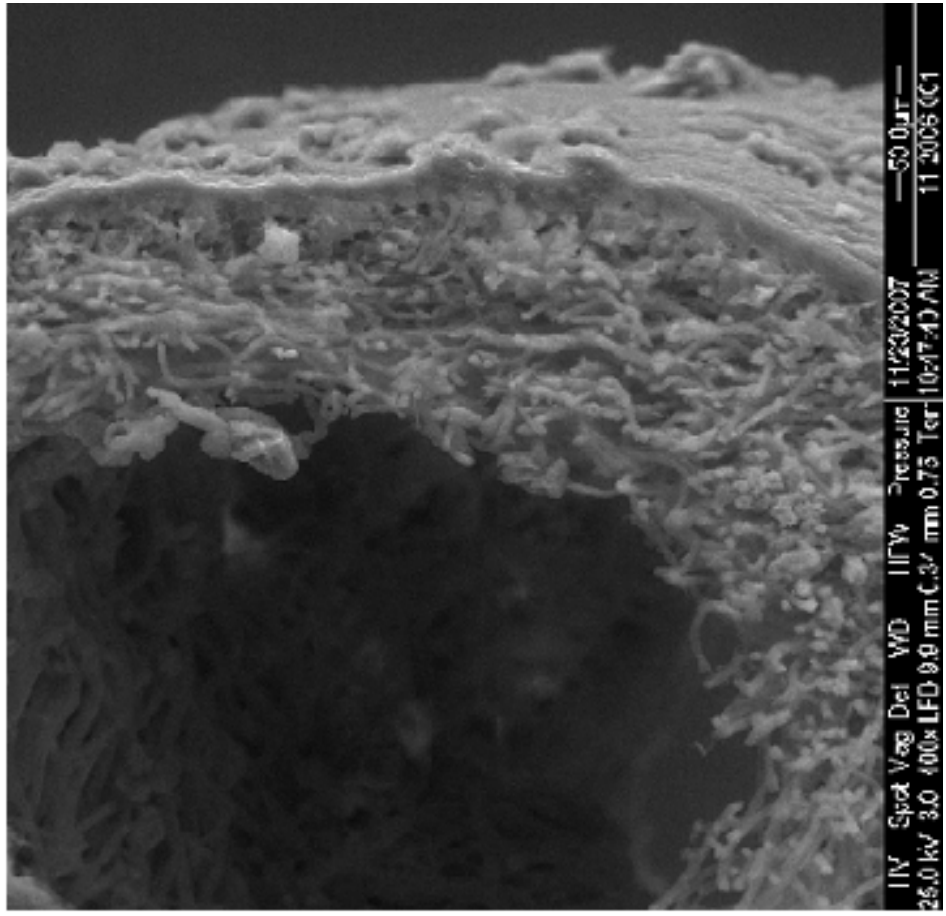

Photo 8. Cross section of lichen thallus of Hypogymnia physodes (L.) Nyl. with visible subcortex layer. Image from electron microscope (photo M.A. Jozwiak), resolution 1000x

C:ArchivelUSERIKLIENTTporeclanalizy12-2006-pow-1600×.spc

Label A: 12-2006-pow-25.01.2008-003

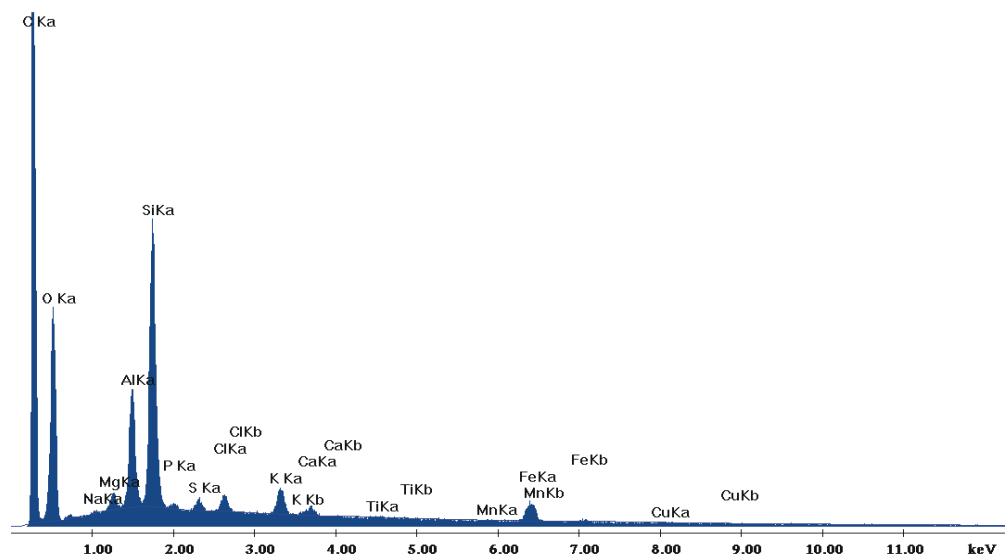

Fig. 4. Chemical analyses EDS of subcortex layer of Hypogymnia physodes (L.) Nyl. 


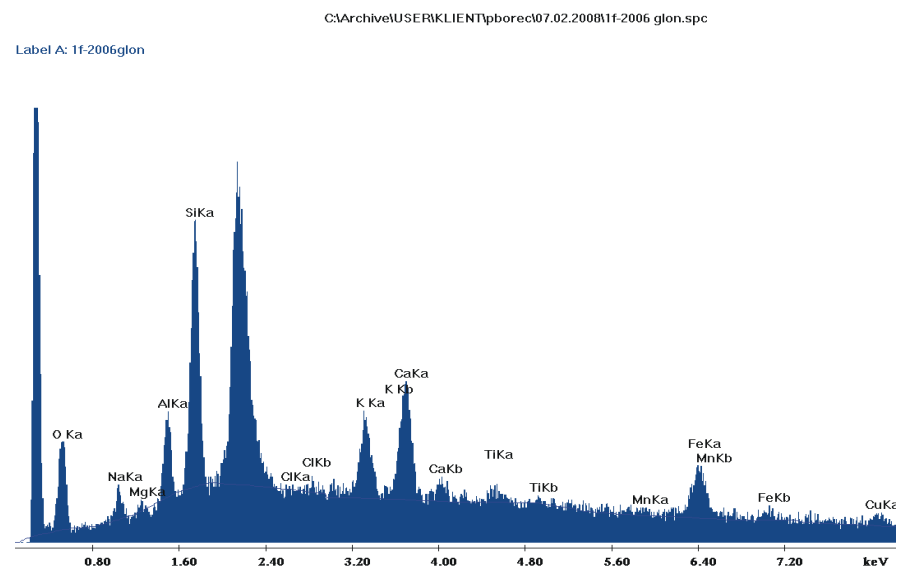

Fig. 5. Chemical analyses EDS from algal cell surface in cracks from parenchyma layer of Hypogymnia physodes (L.) Nyl. thallus

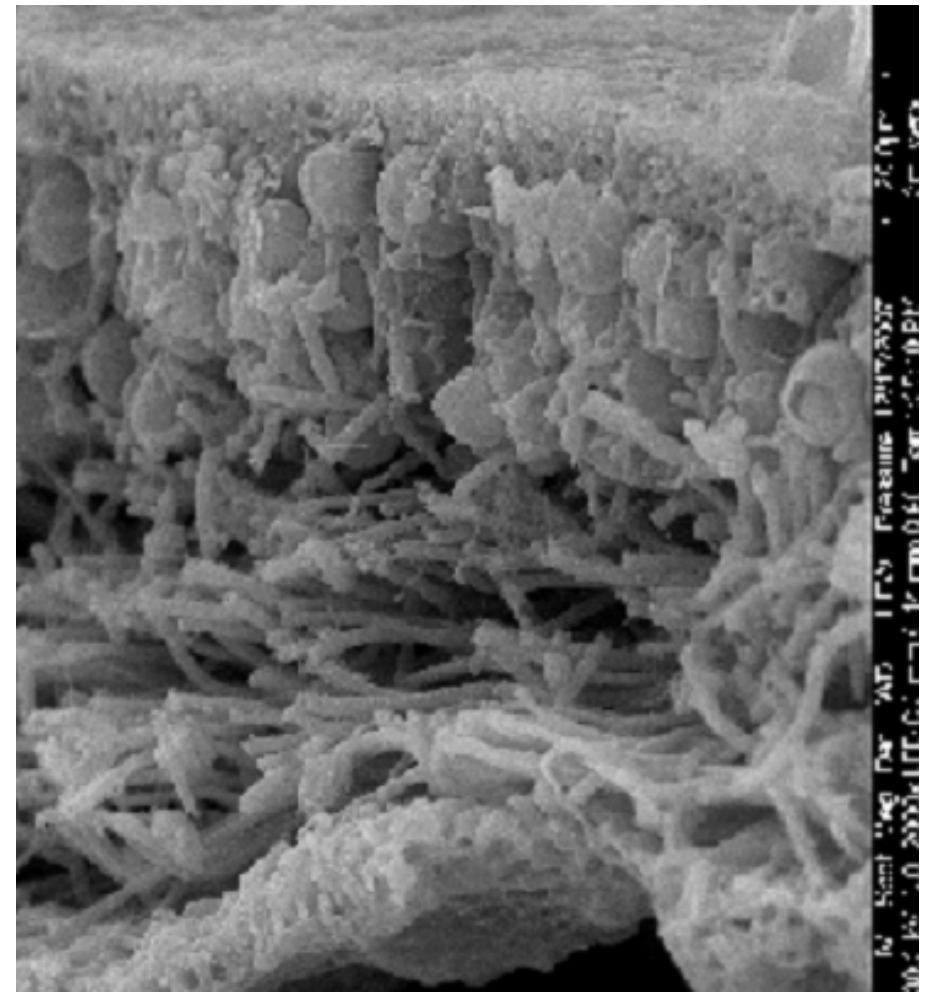

Photo 9. Fungal hyphae of Ascomycetes and rounded cells of Tebouxia sp. in parenchyma layer of Hypogymnia physodes (L.) Nyl. (photo M.A. Jozwiak) 


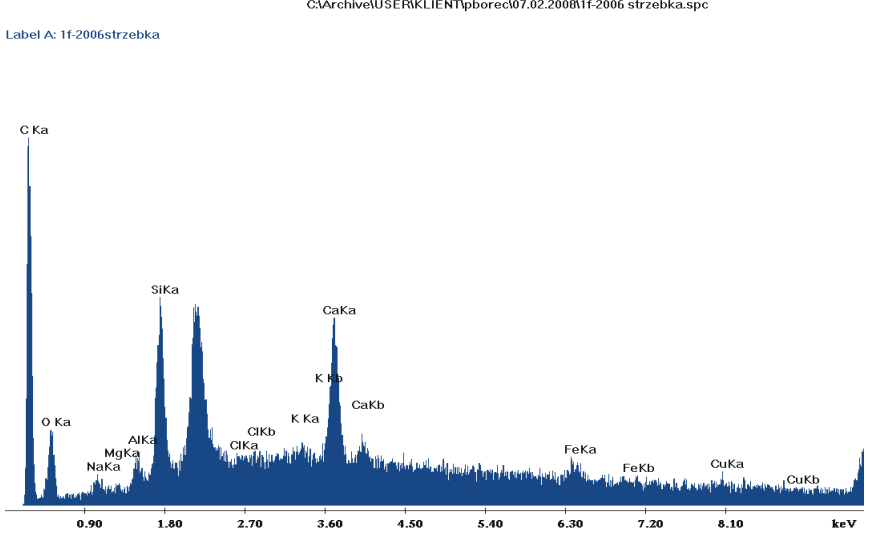

Fig. 6. Chemical analyses EDS from fungal hyphae surface from cracks of parenchyma layer of Hypogymnia physodes (L.) Nyl. thallus

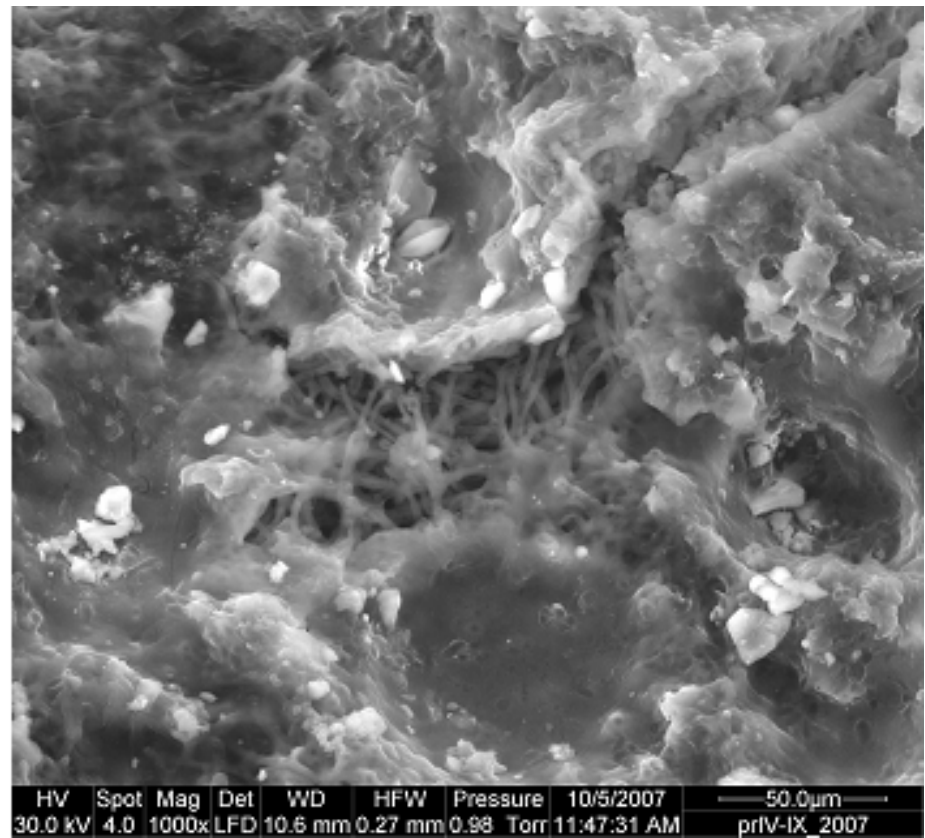

Photo 10. Surface of thallus Hypogymnia physodes (L.) Nyl. Visible cracks of pseudocyphella. Image from electron microscope (photo M.A. Jozwiak), resolution 1000x

What attract attention is the big accumulation of the analyzed heavy metals in fleshy layer on the surface of algal cells, where 18.9 times more metals were found as compared to the control sample and on the surface of mycelium hyphae - 15.5 times more. This is a consequence of exposing the inside of thallus due to natural cracks in the upper surface pseudocyphelia which form a route for gaseous exchange. On the thallus surface of the 
lichens exposed to transit contaminants and directly below it - in the subcortex layer, smaller concentration of metals was found, respectively 7 times more as compared to the control group and 1.7 times more. This point to protective role that mycelium hyphae have in the surface layer.

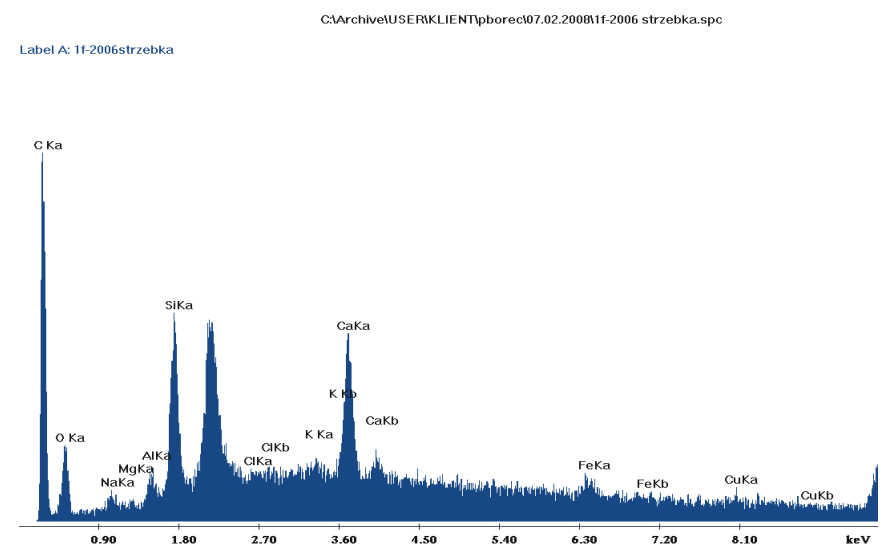

Fig. 7. Chemical analyses EDS in thallus cracks of Hypogymnia physodes (L.) Nyl.

\section{Discussion}

According to Bialonska and Dayan [60] lichens' high sensitivity to contaminants is related to their structure. Without a fully formed protective tissue, cuticle and stomas that enable gaseous exchange, lichens intensively absorb environmental toxins.

The assessment of their usability as bioindicators, supported by many authors [61-64] comes from the lack of dermal layer or any specialized covering tissue that should protect the sensitive gonidial layer located below against contaminants.

Such theses point to absorption of contaminants on the entire surface of the unprotected thallus being spread on the thallus substrate. Precise identification of the areas of high contaminants accumulation in lichen thallus is made possible by analyses conducted with scanning electron microscope and EDAX microanalyzer [41, 42, 65]. These analyses unequivocally corroborate great protective significance of lichen upper cortex layer which in light of the results may be called a "lichen-dermal" layer. Its protective efficiency is dependent on mycelium structure which is very dense in comparison with loose fleshy layer, as well as on the thickness and multi-layeredness of hyphae cell walls that comprise it as compared with the narrow walls of cortex hyphae. Thus, Hypogymnia physodes dorsoventral heteromeric thallus is comprised of two structurally different types of hyphae. Fungal thin-walled cells accompanying algae occur in the gonidial layer and their thinwalledness influences the efficiency of apoplastic water and assimilates transportation in fungus-fungus and fungus-alga associations [66]. The role of multi-layered cell wall in the upper cortex hyphae is to protect the algal cells located below, increased by condensed and tightly interwoven hyphae. Insulating role of lichen's thallus upper cortex was discussed by Armitage and Howe [67] who called attention to the light access regulation. The level of concentration of heavy metals deposited on the thallus surface and under the upper cortex 
layer is a confirmation of the protective role of thallus cortex layer. The study showed that the gates which the contaminants go through are pseudocyphella - numerous cracks used for gaseous exchange located on the thallus surface. Pseudocyphella are cracks or loose spaces in cortex layer. They have up to $4 \mathrm{~mm}$ in diameter and take shape of dots, spots, stars, scars and whitish lines crossing each other and thus forming grids.

They enable absorption of metals in form of cations dissolved in water [68, 69]. Algal and fungal cells exposed through the gaps adsorb significantly greater amounts of contaminants than these located directly below the cortex layer. Pseudocyphella's role in deposition and distribution of contaminants is also corroborated by experimental research by Frey and Scheidegger [66] on Lobaria pulmonaria lichen.

\section{Conclusions}

1. Hypogymnia physodes cortex layer has an important protective role, reducing the probability of contamination inside the thallus. This stems from tight structure of mycelium and thick-walledness and multi-layeredness of hyphae's cell walls.

2. The research shows that the biggest amounts of aluminium, iron and copper are accumulated inside the pseudocyphella gaps. This demonstrates the considerate influence of natural thallus cracks in absorption of contaminants into the lichen.

3. The amount of contaminants accumulated in lichens exposed to the anthropogenic pressure in relation to the place of their accumulation is shown by this juxtaposition:

surface of algal fleshy layer cells $>$ surface of fleshy layer mycelium hyphae $>$ intercell gaps of pseudocyphella cracks $>$ thallus surface - upper cortex $>$ sub-cortex layer

\section{Acknowledgements}

The project was funded by the National Science Centre, N N305 298040.

\section{References}

[1] Nylander W. Les lichens du Jordin du Luxembourg. Bull Soc Bot France. 1866;13:364-372

[2] Harwksworth DL, Rose F. Nature. 1970;227:145-148.

[3] Zurzycki J. Research on arboreal lichens Krakow and the surrounding area. Materials to the physiography of the country. 1950;24:1-30.

[4] Wilkoń-Michalska J, Glazik N, Kalińska A. Acta Univ Nicol Coperni, Biologia, 1968; 29:209-253.

[5] Cieśliński S. Epiphytic lichen flora of Radom. Quarterly Bulletin of the Radom Science Society. 1974;11(3/4):169-189.

[6] Kiszka J. Effect of urban and industrial lichen flora [Lichenes] Krakow and Niepolomicka Forest. HPS monographs in Cracow. 1977;19:1-137

[7] Fałtynowicz W, Izydorek I, Budzbon E. The lichen flora as bioindicator of air pollution of Gdańsk, Sopot and Gdynia. Monogr Bot. 1991;73:1-53.

[8] Kiszka J. Lichens and Przemysl of bioecological conditions. Arboretum Bolestraszyce, 6th Issue Publisher Mercator, 1999; 86 p.

[9] Kiszka J, Koscielniak R. Lichens of Krakow and the valorisation of their bioecological conditions. Stud RIA Document Fizjogr. 1996;24:21-72.

[10] Matwiejuk A. Bialystok lichens as indicators of air pollution. Bialystok: Publisher Economics and the Environment; 2007;102.

[11] Kiszka J. Lichen indication of Krakow region. Stud RIA Document Fizjogr. 1990;18:201-212.

[12] Bylinska EA, Seaward MRD, Kwapulinski J. Sci Total Environ. 1978;41:101-112.

[13] Kiszka J, Grodzińska K. Lichen flora and air pollution in the Niepołomice Forest (S Poland) in 1960-2000. Biologia (Bratislava). 2004;59:25-37. 
[14] Miszalski Z. Sensitivity of lichens on $\mathrm{SO}_{2}$ pollution. Botanic News. 1984;28(4):283-302.

[15] Marska B. The impact of industrial emissions on growth Hypogymnia physodes (L.) Nyl. exhibited in the tables around Chemical Plant "Police". Sci Papers of the Agricult University in Szczecin Natural Series. 1982;29(95):79-87.

[16] Chibowski S, Reszka MJ. Radioanal Nucl Chem. 2001;247(2):443-446. DOI: 10.1023/A:1006798828071

[17] Sawicka-Kapusta K, Zakrzewska M. Air contamination in Swietokrzyski National Park between 1991-2001 using Hypogymnia physodes as bioindicator. Reg Monit of Natural Environ. 2002;3:83-86.

[18] Migaszewski ZM, Gałuszka A, Pasławski P. Polynuclear aromatic hydrocarbons, phenols and trace metals in selected soil profiles and plant bioindicators in the Holy Cross Mountains, south-central Poland. Environ Internat. 2002;28(4):303-313. DOI: 10.1016/S0016-7037(02)00873-6.

[19] Migaszewski ZM, Gałuszka A, Pasławski P. Baseline element concentrations in soils and plant bioindicators of selected national parks of Poland. Geol Quart. 2004;48(4):383-394.

[20] Jóźwiak MA, Jóźwiak M. Environ and Natural Res. 2009;40:419-429.

[21] Jóźwiak MA, Jóźwiak M. Assessment of air pollution in Kielce, based on biomonitoring as part of monitoring the implementation of sustainable development of natural and environmental management. Kielce Sientific Society. 2011; 45 p.

[22] Kłos A, Rajfur M, Ciesielczuk T, Wacławek M, Wacławek W. Ecol Chem Eng S. 2008: 15(1):77-84.

[23] Pacheco AMG, Freitas MC, Barros LIC, Figueira R. J Radioanal Nucl Chem. 2001; 247(2):327-331.

[24] Pacheco AMG, Freitas MC. J Radioanal Nucl Chem. 2004;259(1):27-33.

[25] Freitas MC, Pacheco AMG, Marques AP, Barros LIC, Reis MA. Applications of nuclear analytical techniques to environmental studies. AIP Confer Proc. 2001;576(1):508-511.

[26] Garty J. Canad J Bot. 1988; 66(4):668-682.

[27] Garty J, Kauppi M, Kauppi A. The influence of air pollution on the concentration of airborne elements and on the production of stress-ethylene in the lichen Usnea hirta (L) Weber em Mot transplanted in urban sites in Oulu, N Finland. Arch Environ Contam Toxicol. 1997;32:285-290.

[28] Garty J, Delarea J. Symbiosis. 1987;3:49-56.

[29] Grasso MF, Clocchiatti R, Deschamps C, Vurro F. Environ Geol. 1999;37(3):207-217.

[30] Varrica D, Aiuppa A, Dongarra G. Environ Pollut. 2000;108:153-162. DOI: 10.1016/S02697491(99)00246-8.

[31] Bargagli R, Barghigiani C. Environ Monit Assess. 1991;69(4):337-348.

[32] Loppi S, Nelli L, Ancora S, Bargagli R. Passive monitoring of trace elements by means of tree leaves, epiphytic lichens and bark substrate. Environ Monit Assess. 1997;45:81-88. DOI: 10.1023/A:1005770126624.

[33] Loppi S, Frati L, Paoli L, Bigagli V, Rossetti C, Bruscoli C, et al. Biodiversity of epiphytic lichens and heavy metal contents of Flavoparmelia caperata thalli as indicators of temporal variations of air pollution in the town of Montecatini Terme (central Italy). Sci Total Environ. 2004;326:113-122. DOI: 10.1016/j.scitotenv.2003.12.003.

[34] Scerbo R, Possenti L, Lampugnani L, Ristori T, Barale R, Barghigiani C. Sci Total Environ. 1999;286:27-40.

[35] Pla RR, Moreno MA, Adler M. The use biomonitors and neutron activation analysis in the study of air pollution of Buenos Aires city. In: Biomonitoring of Atmospheric Pollution (with Emphasis on Trace Elements) - BioMap. IAEA (ed). Lisbon, Portugal: IAEA; 2000;122-128.

[36] Jasan RC, Verburg TG, Wolterbeek HTh, Plá RR, Pignata ML. On the use of the lichen Ramalina celastri (Spreng.) Krog. \& Swinsc. as an indicator of atmospheric pollution in the province of Cordoba, Argentina, considering both lichen physiological parameters and element concentrations. J Radioanal Nuclear Chem. 2004;259:93-97. DOI: 10.1023/B:JRNC.0000015812.46333.41.

[37] Bubach DF, Arribere MA, Riberio Guevara S, Calvelo S. Study on the feasibility of using transplanted Protousnea magellanica thalli as a bioindicator of atmospheric contamination J Radioanal Nuclear Chem. 2001;250(3):63-68.

[38] Tuncel SG, Yenisoy-Karakas S. Water Air Soil Pollut. 2003;3:97-107.

[39] Yenisoy-Karakas S, Tuncel SG. J Radioanal Nuclear Chem. 2004;259(1):113-118.

[40] Jeran Z, Jaćimović R, Batič F, Smodiš B, Wolterbeek HT. Atmospheric heavy metal pollution in Slovenia derived from results for epiphytic lichens. J Anal Chem. 1996;354:681-687.

[41] Jaćimović R, Batič F, Kostelec D, Mavasar R, Simoničič P. Epiphytic lichens as biomonitors of atmospheric pollution in Slovenian forest. Environ Pollut. 2007;146:324-331. DOI: 10.1016/j.envpol.2006.03.032.

[42] Jeran Z, Jaćimović R, Batič F, Mavsar R. Lichens as integrating air pollution monitors. Total Environ. 2002;120:107-113. DOI: 10.1016/S0269-7491(02)00133-1. 
[43] Ford J, Landers D, Kugler D, Lasorsa B, Allen-Gil S, Crecelius E. Sci Total Environ. 1995;160/161:323-35.

[44] Pilegaard K. Bioscience. 1994;43:20.

[45] Poblet A, Andrade S, Scagliola M, Vodopivez C, Curtosi A, Pucci A, et al. The use of epilithic Antarctic lichens (Usnea aurantiacoatra and U-antartica) to determine deposition patterns of heavy metals in the Shetland Islands, Antarctica. Sci Total Environ. 1997;207:187-194. DOI: 10.1016/S0048-9697(97)00265-9.

[46] Grodzinska K, Godzik B, Szarek G. Heavy metals and sulphur in lichens from southern Spitsbergen. Fragm Flor Geobot Suppl. 1993;2(2):699-708.

[47] Olech M. Polish Polar Res. 1991;12(1):129-131.

[48] Olech M, Osyczka P, Dutkiewicz EM. Polish Polar Stud. 2000;99:99-103.

[49] Freitas MC, Reis MA, Marques AP, Wolterbeek HT. J Radioanal Nuclear Chem. 2001;49(2):307-315.

[50] Kłos A, Rajfur M, Wacławek M, Wacławek W. Environ Prot Eng. 2009;3:105-121.

[51] Jóźwiak MA, Jóźwiak M, Kozłowski R. Monographs of Systems Operations Team PAS. 2010;2:177-199.

[52] Jóźwiak MA. Ecol Chem Eng S. 2012;19(4):549-569.

[53] Nash III THE. editor. Lichen Biology. Cambridge: Cambridge University Press; 2008.

[54] Piotrowski J. Basics of Toxicology. Warsaw: Publisher of Science and Technology; 2006

[55] Garty J. Biomonitoring heavy metal pollution with Lichens. In: Kranner I, Beckett RP, Varma AK, editors. Protocols in Lichenology, Berlin: Springer; 2002;458-482.

[56] Kranner I, Beckett RP, Varma AK, editors. Protocls in lichenology. Culturing, biochemistry, ecophysiology and use in biomonitoring. Berlin, Heidelberg, New York: Springer-Verlag; 2002.

[57] Brown RM, Wilson R. J Phytol. 1968;4:230-240.

[58] Majeti NV, Kumar R. A review of chitin and chitosan applications. Reactive and Functional Polymers. 2000;46:1-27.

[59] Zarzycki R, Modrzejewska Z. J Chem Eng Technol. 2003;3:324-327.

[60] Białońska D, Dayan FE. J Chem Ecol. 2005;31:2975-2991.

[61] Malcolm WM, Galloway DJ. New Zeland Lichens, Museum of New Zeland te papa Tongarewa; 1997.

[62] Fałtynowicz W. Using lichens to assess air pollution. Krosno: Rural Environ Educat Center; 1995;141.

[63] Wójciak H. Lichens, Bryophytes, Pteridophytes. Polish Flora. Warsaw: Multico; 2007.

[64] Szweykowscy AJ. Botanic. Morphology. Warsaw: NSP; 2008.

[65] Jóźwiak MA, Jóźwiak M. Ecol Chem Eng S. 2009;16(3):323-334.

[66] Frey B, Scheidegger Ch. Preparative Techniques for Low Temperature Scanninge Electron Microscopy of Lichens, In: Kranner I, Beckett RP, Varma AK, editors. Protocols in Lichenology. London: Springer; 2002;118-134.

[67] Armitage MH, Howe GF. The ultrastucture of lichen cells supports creation, not macroevolution. CRSQ. 2007;44(1):40-53.

[68] Garty J, Levin T, Cohen Y, Lehr H. Biomonitoring air pollution with the desert lichen Ramalina maciformis. Physiologia Plantarum. 2002;115:267-275. DOI: 10.1034/j.1399-3054.2002.1150213.x

[69] Garty J, Tamir O, Levin T, Lehr H. Environ Pollut. 2006;145:266-273. DOI: 10.1016/j.envpol.2006.03.022.

\title{
EKTOHYDRYCZNOŚĆ POROSTÓW I ROLA WARSTWY KOROWEJ W AKUMULACJI METALI CIĘŻKICH
}

\author{
Katedra Ochrony i Kształtowania Środowiska, Uniwersytet Jana Kochanowskiego w Kielcach
}

\begin{abstract}
Abstrakt: Wchłanianie metali ciężkich i zanieczyszczeń pyłowych przez plechy porostowe odbywa się na drodze powierzchniowej, tzw. ektohydrycznej sorpcji. Istotną rolę w ograniczeniu tego procesu odgrywają naturalne mechanizmy ochronne, m.in. heteromeryczna (warstwowa) budowa porostów. Celem badań było określenie dróg przenikania zanieczyszczeń w głąb plechy porostów oraz określenie roli warstwy dermalnej w zatrzymywaniu metali ciężkich na powierzchni plechy. Analizie poddano plechy porostowe, które przez okres pół roku eksponowano na zanieczyszczenia komunikacyjne przy autostradzie Kraków - Katowice. Przy wykorzystaniu skaningowego mikroskopu elektronowego Quanta 250 oraz mikroanalizatora EDAX określano kumulację zanieczyszczeń osadzających się na zewnętrznej powierzchni plechy, na powierzchni komórek glonowych, w warstwie podkorowej, na powierzchni strzępków grzybowych i w przestrzeniach międzykomórkowych dna szczeliny pseudocyfeli. Wyniki analiz wskazują na istotną rolę szczelin pseudocyfeli w procesie przenikania zanieczyszczeń w głąb plechy porostu oraz skuteczność ochronną warstwy kory górnej, której zwarta struktura oraz grubość chitynowych ścian komórek grzybni jest relatywnie grubsza w stosunku do grzybni warstwy
\end{abstract}


miąższowej, co decyduje o jej właściwościach dermalnych. Kumulację metali ciężkich (Al, Fe, Cu) na powierzchni plechy, powierzchni komórek glonowych, w warstwie podkorowej, na powierzchni strzępków grzybowych i w przestrzeniach międzykomórkowych dna szczeliny pseudocyfeli przedstawia układ szczelina > glon > grzyb > warstwa podkorowa > powierzchnia plechy.

Słowa kluczowe: plecha porostu, mechanizmy ochronne, warstwa dermalna, zanieczyszczenie metalami ciężkimi 